\title{
Effects of the interaction between vapor-pressure deficit and salinity on growth and photosynthesis of Cucumis sativus seedlings under different $\mathrm{CO}_{2}$ concentrations
}

\author{
T. SHIBUYA ${ }^{+}$, K. KANO, R. ENDO, and Y. KITAYA \\ Graduate School of Life and Environmental Sciences, Osaka Prefecture University, Sakai, Osaka - 599 8531, Japan
}

\begin{abstract}
We studied growth and photosynthesis of cucumber (Cucumis sativus) seedlings under two vapor-pressure deficit levels (VPD; 0.4 and $3.0 \mathrm{kPa}$ ), two salinity levels $(0$ and $34 \mathrm{mM} \mathrm{NaCl})$, and two $\mathrm{CO}_{2}$ concentrations $\left(\left[\mathrm{CO}_{2}\right] ; 400\right.$ and $1,000 \mu \mathrm{mol}$ $\mathrm{mol}^{-1}$ ). Relative growth rate (RGR) decreased with increasing VPD, but the causal factor differed between salinity levels and $\mathrm{CO}_{2}$ concentrations. Under ambient $\left[\mathrm{CO}_{2}\right], \mathrm{RGR}$ decreased with increasing VPD at low salinity mainly due to decreased leaf area ratio (LAR), and decreased net assimilation rate (NAR) at high salinity. The decrease in intercellular $\left[\mathrm{CO}_{2}\right]\left(C_{\mathrm{i}}\right)$ with decreasing stomatal conductance caused by high VPD did not significantly limit net photosynthetic rate $\left(P_{\mathrm{N}}\right)$ at low salinity, but $P_{\mathrm{N}}$ was potentially limited by $C_{\mathrm{i}}$ at high salinity. At high $\left[\mathrm{CO}_{2}\right]$, high VPD reduced LAR, but did not affect NAR. This is because the decrease in $C_{\mathrm{i}}$ occurred where slope of $P_{\mathrm{N}}-C_{\mathrm{i}}$ curve was almost flat.
\end{abstract}

Additional key words: evaporative demand; gas exchange; growth analysis; humidity; stress response; water potential.

\section{Introduction}

The vapor-pressure deficit (VPD), which creates evaporative demand, influences the water balance of plants that in turn affects their photosynthesis and growth. Controlling VPD is therefore an effective strategy for improving crop yield in protected cultivation ( $\mathrm{Lu}$ et al. 2015, Zhang et al. 2015), because high evaporative demand can inhibit plant growth. The reduction of plant growth with increasing VPD has two main causes: reduction of photosynthesis per unit leaf area due to water stress, or reduction of the whole-plant light interception area due to decreasing leaf expansion.

There have been many reports that greater evaporative demand decreases photosynthesis and plant growth by decreasing stomatal conductance $\left(g_{\mathrm{s}}\right)$ (Raschke and Resemann 1986, Dai et al. 1992, van de Sanden and Veen 1992, Wong 1993, Ottosen et al. 2002, Ben-Asher et al. 2013). On the other hand, several studies have suggested that high evaporative demand may not decrease photo- synthesis even if it reduces $g_{\mathrm{s}}$ (Carins-Murphy et al. 2014, Shibuya et al. 2016b). For the reduction of the light interception area, many researchers have reported that higher evaporative demand reduces leaf expansion (Salah and Tardieu 1997, Munns et al. 2000, Tardieu et al. 2000, 2010, Körner and Challa 2003, Zhang et al. 2015). This, in turn, decreases whole-plant light interception and photosynthesis, although contradictory results have also been reported (van de Sanden and Veen 1992, Wong 1993). The existence of contradictory results for the photosynthetic rate and leaf expansion indicates that one or more other factors interact with regulation of photosynthesis and light interception area to affect the responses of plants to high evaporative demand.

Here, we focused on the salinity, which affects water uptake, and the atmospheric $\mathrm{CO}_{2}$ concentration $\left(\left[\mathrm{CO}_{2}\right]\right)$, which affects $\mathrm{CO}_{2}$ assimilation, as potential interactive factors. The rhizosphere water status and VPD both affect

Received 8 March 2017, accepted 17 May 2017, published as online-first 22 June 2017.

${ }^{+}$Corresponding author, fax: +81-72-254-9433, e-mail: shibuya@envi.osakafu-u.ac.jp

Abbreviations: $\mathrm{AC}$ - ambient $\left[\mathrm{CO}_{2}\right] ;$ ANOVA - analysis of variance; $\left[\mathrm{CO}_{2}\right]-\mathrm{CO}_{2}$ concentration; $C_{\mathrm{i}}-$ intercellular $\mathrm{CO}_{2}$ concentration; $\mathrm{DM}$ - dry mass; EC - elevated $\left[\mathrm{CO}_{2}\right] ; g_{\mathrm{s}}$ - stomatal conductance; $J_{300}$ and $J_{1500}$ - electron transport rates at photosynthetic photon flux densities of 300 and $1,500 \mu \mathrm{mol} \mathrm{m}^{-2} \mathrm{~s}^{-1}$, respectively; LAR - leaf area ratio; LMR - leaf mass ratio; NAR - net assimilation rate; $P_{\mathrm{N}}-$ net photosynthetic rate; $\Psi_{1}$ - leaf water potential; RGR - relative growth rate; SLA - specific leaf area; $V_{\mathrm{cmax}}$ - maximum rate of Rubisco carboxylase activity; VPD - vapor-pressure deficit.

Acknowledgements: This research was supported by a Japan Society for the Promotion of Science Grant-in-Aid for Scientific Research (B) (KAKENHI 15H04575). The authors thank Ryo Matsuda (University of Tokyo) and Masahito Ueyama (Osaka Prefecture University) for valuable discussion of the experimental results, and Norio Hirai (Osaka Prefecture University) for his valuable help in our statistical analysis. The authors also thank referees and editors for their careful reading and valuable suggestions to improve this paper. 
plant water relations, and thus can interactively affect photosynthesis (Xue et al. 2004, El-Sharkawy 2011) and leaf expansion (van de Sanden and Veen 1992, Tardieu et al. 2000). $\left[\mathrm{CO}_{2}\right]$ and VPD, which is one of the driving forces for $\mathrm{CO}_{2}$ and vapor diffusion, can also interact with other factors to affect photosynthetic properties (Gislerød and Nelson 1989, Wong 1993). However, most previous studies were conducted under conditions in which neither parameter was fully controlled, or growth and photosynthetic properties were not investigated simultaneously, thereby preventing a more comprehensive explanation of interacting effects. In addition, the simultaneous effects of the three factors (VPD, rhizosphere conditions, and $\left[\mathrm{CO}_{2}\right]$ ) have not been investigated. This is an important omission,

\section{Materials and methods}

Growth conditions: Cucumber (Cucumis sativus L. cv. 'Hokushin') seeds were sown individually in vermiculite in plastic cell trays (cell size: $25-\mathrm{mm}$ square) and germinated in a custom-designed growth chamber (Ikeya Co., Kashiba, Japan) maintained at an air temperature of $28^{\circ} \mathrm{C}$, a VPD of $0.4 \mathrm{kPa}$ (relative humidity of $90 \%$ ), and $\left[\mathrm{CO}_{2}\right]$ of $400 \mu \mathrm{mol} \mathrm{mol} \mathrm{m}^{-1}$ until the cotyledons had expanded ( $6 \mathrm{~d}$ after seeding). Illumination was supplied by fluorescent lamps (FPL55EX-N; Panasonic Corp., Kadoma, Japan) with a PPFD of $300 \mu \mathrm{mol} \mathrm{m} \mathrm{m}^{-2} \mathrm{~s}^{-1}$. The light:dark period was $16-\mathrm{h}$ light/8-h dark throughout the experiment. The seedlings were transplanted into plastic bottles $(250 \mathrm{~mL})$ containing nutrient solution (details below) and then grown hydroponically in the growth chambers (Ikeya Co., Kashiba, Japan) maintained at a VPD of $0.4 \mathrm{kPa}$ (hereafter, low VPD) or $3.0 \mathrm{kPa}$ (hereafter, high VPD) and at $\left[\mathrm{CO}_{2}\right]$ of $400 \mu \mathrm{mol} \mathrm{mol}{ }^{-1}$ (hereafter, ambient $\left[\mathrm{CO}_{2}\right], \mathrm{AC}$ ) or $1,000 \mu \mathrm{mol} \mathrm{mol}{ }^{-1}$ (hereafter, elevated $\left.\left[\mathrm{CO}_{2}\right], \mathrm{EC}\right)$ for $8 \mathrm{~d}$. These VPD values correspond to a relative humidity of 90 and $20 \%$, respectively, at an air temperature of $28^{\circ} \mathrm{C}$. Nutrient solutions (the A-type recipe of OAT Solution; OAT Agrio Co. Ltd., Tokyo, Japan) were supplied at two different salinity levels $(0 \mathrm{mM}$ and $34 \mathrm{mM}$ $\mathrm{NaCl}$, hereafter, the low and high salinity, respectively) as the growing medium. The composition of the standard nutrient solution in $\mathrm{mEq} \mathrm{L}^{-1}$ was: $\mathrm{N}, 18.6$; $\mathrm{P}, 5.1 ; \mathrm{K}, 8.6$; $\mathrm{Ca}, 8.2 ; \mathrm{Mg}, 3.0$. The electrical conductivity was $2.6 \mathrm{mS}$ $\mathrm{cm}^{-1}$, and the $\mathrm{pH}$ value was 6.5 . The high salinity treatment was created by adding $\mathrm{NaCl}(0.2 \% \mathrm{w} / \mathrm{v})$ to the standard solution; this increased electrical conductivity to $5.0 \mathrm{mS}$ $\mathrm{cm}^{-1}$. The osmotic potential values, which were estimated from the electrical conductivity values using the equation of Richards (1954), were -0.09 and $-0.18 \mathrm{MPa}$ in low and high salinity, respectively. The nutrient solution was added to the bottles during the growing period to replace losses to evaporation. The seedlings were arranged with sufficient space to avoid mutual shading among neighboring seedlings.

Growth analysis: We sampled 12 seedlings in each because it is possible that the interaction of two factors may be altered by changes in the third factor. A better understanding of these possible interactions will help us to interpret the results obtained under different environmental conditions.

In the present study, growth and photosynthetic properties of cucumber (Cucumis sativus L.) seedlings grown under two VPD levels, two salinity levels of the nutrient solution, and two $\mathrm{CO}_{2}$ concentrations were determined by means of growth analysis and gas-exchange measurements to reveal the potential interactions among these factors and to determine underlying causal factor or factors that limit plant growth under high evaporative demand.

treatment group at $6 \mathrm{~d}$ after seeding (at the start of the treatments) and ten seedlings in each group at $14 \mathrm{~d}$. This growing period seems short, but our previous research suggested that it is long enough to evaluate the initial growth of cucumber seedlings (Shibuya et al. 2016a). We measured the leaf area of each seedling using an image scanner and the LIA32 for Win image analysis software (K. Yamamoto, Nagoya University, Nagoya, Japan), and then determined the whole-plant and leaf dry masses (DM, measured after $3 \mathrm{~d}$ of drying at $80^{\circ} \mathrm{C}$ ). The relative growth rate $\left(\mathrm{RGR}, \mathrm{g} \mathrm{g}^{-1} \mathrm{~d}^{-1}\right.$ ), net assimilation rate (NAR, $\mathrm{g} \mathrm{m}^{-2} \mathrm{~d}^{-1}$ on DM basis), leaf area ratio (LAR, $\mathrm{m}^{2} \mathrm{~g}^{-1}$ ), specific leaf area (SLA, $\mathrm{m}^{2} \mathrm{~g}^{-1}$ ), and leaf mass ratio (LMR, dimensionless) were calculated using the following equations (Radford 1967, Hunt et al. 2002):

$$
\begin{aligned}
& \mathrm{RGR}=\frac{\ln W_{2}-\ln W_{1}}{t_{2}-t_{1}}=\mathrm{NAR} \times \mathrm{LAR} \\
& \mathrm{NAR}=\frac{W_{2}-W_{1}}{A_{2}-A_{1}} \times \frac{\ln A_{2}-\ln A_{1}}{t_{2}-t_{1}} \\
& \mathrm{LAR}=\frac{A_{2}-A_{1}}{\ln A_{2}-\ln A_{1}} \times \frac{\ln W_{2}-\ln W_{1}}{W_{2}-W_{1}}=\mathrm{SLA} \times \mathrm{LMR} \\
& \mathrm{SLA}=\frac{A_{2}-A_{1}}{\ln A_{2}-\ln A_{1}} \times \frac{\ln L_{2}-\ln L_{1}}{L_{2}-L_{1}} \\
& \mathrm{LMR}=\frac{L_{2}-L_{1}}{\ln L_{2}-\ln L_{1}} \times \frac{\ln W_{2}-\ln W_{1}}{W_{2}-W_{1}}
\end{aligned}
$$

where $W_{1}$ and $W_{2}$ are the whole-plant DM [g] at times $t_{1}$ and $t_{2}$ (6 and $14 \mathrm{~d}$ after seeding, respectively), $A_{1}$ and $A_{2}$ are the corresponding total leaf areas $\left[\mathrm{m}^{2}\right]$, and $L_{1}$ and $L_{2}$ are the corresponding leaf DM values [g]. The averages of $W_{1}, A_{1}$, and $L_{1}$ (from 12 seedlings) were used as representative values at $t_{1}$ for calculation.

Photosynthetic properties and water status: We measured the net photosynthetic rate $\left(P_{\mathrm{N}}\right)$ and $g_{\mathrm{s}}$ of the first true leaf in ten seedlings $14 \mathrm{~d}$ after seeding using an LI-6400 photosynthesis system (LI-COR Inc., Lincoln, NE, USA) at a measurement PPFD of $300 \mu \mathrm{mol} \mathrm{m} \mathrm{m}^{-2} \mathrm{~s}^{-1}$ (the same as the growing conditions) or $1,500 \mu \mathrm{mol} \mathrm{m}{ }^{-2} \mathrm{~s}^{-1}$ (saturating light intensity), at a leaf temperature of $28^{\circ} \mathrm{C}$. Different seedlings were used for each PPFD measurement. Illumination was supplied by red and blue LEDs at 
a ratio of 9:1. The measurements were conducted at $\left[\mathrm{CO}_{2}\right]$ of $70,100,150,200,400,800$, and (only for EC treatments) $1,000 \mu \mathrm{mol} \mathrm{mol}{ }^{-1}$ for a PPFD of $300 \mu \mathrm{mol}$ $\mathrm{m}^{-2} \mathrm{~s}^{-1}$ and of $70,100,150,200,400,600$, and $800 \mu \mathrm{mol}$ $\mathrm{mol}^{-1}$ for saturating light. The VPD in the measuring system was maintained at approximately 1.2 or $2.6 \mathrm{kPa}$ for the seedlings grown under low or high VPD, respectively. These measurement VPD are near the minimum and maximum for this equipment. Intercellular $\left[\mathrm{CO}_{2}\right]\left(C_{\mathrm{i}}\right)$ was calculated according to the method of von Caemmerer and Farquhar (1981). The electron transport rates at PPFDs of 300 and $1,500 \mu \mathrm{mol} \mathrm{m}{ }^{-2} \mathrm{~s}^{-1}$ ( $J_{300}$ and $J_{1500}$, respectively) were estimated from the $P_{\mathrm{N}}-C_{\mathrm{i}}$ curves using a curve-fitting model developed by Sharkey et al. (2007). The maximum rate of Rubisco carboxylase activity $\left(V_{\mathrm{cmax}}\right)$ was estimated from the $P_{\mathrm{N}}-C_{\mathrm{i}}$ curves at the saturating light intensity using the same model.

Leaf water potential $\left(\Psi_{1}\right)$ of the first true leaf was measured for another five seedlings in each treatment group using a dewpoint potentiometer (WP4-T; Decagon Devices, Inc., Pullman, WA, USA) according to the manufacturer's

\section{Results}

Growth parameters: RGR tended to decrease with increasing VPD and increasing salinity, but their interaction differed between the $\mathrm{CO}_{2}$ concentrations (Table 1). At AC, there was a significant VPD $\times$ salinity interaction for RGR, with a stronger VPD effect at high salinity; RGR at high VPD was 83 and 93\% (for high and low salinity, respectively) of the corresponding values at low VPD. On the other hand, at EC, the interaction was not significant, but the effect of VPD on RGR tended to be greater at low salinity; at low salinity, RGR at high VPD was $91 \%$ of that at low VPD, but there was no significant difference between the two treatments at high salinity. The wholeplant DM showed similar results (Fig. 1 $A, B$ ).

NAR was only significantly affected by VPD at high salinity under AC; NAR was lower at high VPD (Table 1). recommendations. The measurement of $\Psi_{1}$ was conducted approximately at the middle of photoperiod.

Statistical analysis: The effects of the VPD $\times$ salinity interaction on growth parameters, photosynthetic properties, and water status at each $\left[\mathrm{CO}_{2}\right]$ were determined by means of two-way analysis of variance (ANOVA). Analysis of the whole-plant DM was performed after logarithmic transformation of the data. Significant differences in these values between the treatments in each $\left[\mathrm{CO}_{2}\right]$ were then identified by means of the TukeyKramer's test (with significance at $P<0.05$ ). The effects of the VPD $\times\left[\mathrm{CO}_{2}\right]$ interaction at each salinity level were also determined. One sample used to determine the growth parameters was excluded from the combination of low VPD, low salinity, and AC because its RGR was an outlier (based on the results of the $G r u b b^{\prime}$ s test at $P<0.05$ ). All analyses were performed using the Statcel 2 software (OMS Publishing Inc., Tokorozawa, Japan). The experiments were not replicated, but were conducted under a precisely controlled environment.

There was a significant VPD $\times$ salinity interaction for NAR at AC; high VPD did not significantly affect NAR at low salinity, but at high salinity, it significantly decreased NAR, to $82 \%$ of the value at low VPD. No significant interaction was observed for NAR at EC; the NAR was not significantly affected by either VPD or salinity.

There was a significant VPD $\times$ salinity interaction for LAR (Table 1). LAR tended to decrease at high VPD under both $\left[\mathrm{CO}_{2}\right]$, but only at low salinity; LAR decreased to 94 and $91 \%$ of the value at low VPD under AC and EC, respectively. SLA showed similar results to LAR, indicating that the smaller LAR under high VPD resulted from decreased SLA. LMR was not significantly affected by VPD except at high salinity under AC.

Table 1. Relative growth rate (RGR) $\left[\mathrm{g} \mathrm{g}^{-1} \mathrm{~d}^{-1}\right]$, net assimilation rate (NAR) $\left[\mathrm{g} \mathrm{m}^{-2} \mathrm{~d}^{-1}\right]$, leaf area ratio (LAR) [m² $\left.\mathrm{g}^{-1}\right]$, specific leaf area (SLA) $\left[\mathrm{m}^{2} \mathrm{~g}^{-1}\right]$, and leaf mass ratio (LMR) $\left[\mathrm{g} \mathrm{g}^{-1}\right]$ of cucumber (Cucumis sativus) seedlings grown under different combinations of vapor-pressure deficit, salinity of the nutrient solution, and atmospheric $\mathrm{CO}_{2}$ concentration $\left(\left[\mathrm{CO}_{2}\right]\right.$; ambient $\left[\mathrm{CO}_{2}\right], \mathrm{AC}$, and elevated $\left.\left[\mathrm{CO}_{2}\right], \mathrm{EC}\right)$ for $8 \mathrm{~d}$ after transplantation. Data are the average of ten replicate plants $(n=10)$, except for the combination of low VPD, low salinity, and ambient $\left[\mathrm{CO}_{2}\right](n=9)$. Mean values of a parameter at a given $\left[\mathrm{CO}_{2}\right]$ that are labelled with different letters, differed significantly (Tukey-Kramer's test, $P<0.05)$.

\begin{tabular}{|c|c|c|c|c|c|c|c|c|c|c|c|}
\hline \multirow[t]{2}{*}{ Salinity } & \multirow[t]{2}{*}{ VPD } & \multicolumn{5}{|c|}{$\mathrm{AC}\left(400 \mu \mathrm{mol} \mathrm{mol}{ }^{-1}\right)$} & \multicolumn{5}{|c|}{$\mathrm{EC}\left(1,000 \mu \mathrm{mol} \mathrm{mol}{ }^{-1}\right)$} \\
\hline & & RGR & NAR & LAR & SLA & LMR & RGR & NAR & LAR & SLA & LMR \\
\hline \multirow{2}{*}{$\begin{array}{l}\text { Low } \\
(0 \mathrm{mM} \mathrm{NaCl})\end{array}$} & Low $(0.4 \mathrm{kPa})$ & $0.309^{\mathrm{a}}$ & $13.7^{\mathrm{a}}$ & $0.0226^{\mathrm{a}}$ & $0.0309^{\mathrm{a}}$ & $0.733^{\mathrm{b}}$ & $0.340^{\mathrm{a}}$ & $15.6^{\mathrm{a}}$ & $0.0218^{\mathrm{a}}$ & $0.0300^{\mathrm{a}}$ & $0.730^{\mathrm{b}}$ \\
\hline & $\operatorname{High}(3.0 \mathrm{kPa})$ & $0.288^{\mathrm{b}}$ & $13.5^{\mathrm{a}}$ & $0.0213^{\mathrm{b}}$ & $0.0292^{\mathrm{b}}$ & $0.731^{\mathrm{b}}$ & $0.310^{\mathrm{b}}$ & $15.6^{\mathrm{a}}$ & $0.0199^{\mathrm{b}}$ & $0.0264^{\mathrm{b}}$ & $0.747^{\mathrm{ab}}$ \\
\hline \multirow{2}{*}{$\begin{array}{l}\text { High } \\
(34 \mathrm{mM} \mathrm{NaCl})\end{array}$} & Low $(0.4 \mathrm{kPa})$ & $0.277^{\mathrm{b}}$ & $13.7^{\mathrm{a}}$ & $0.0204^{b}$ & $0.0272^{b}$ & $0.749^{\mathrm{a}}$ & $0.302^{\mathrm{b}}$ & $15.6^{\mathrm{a}}$ & $0.0195^{\mathrm{b}}$ & $0.0254^{\mathrm{b}}$ & $0.762^{\mathrm{a}}$ \\
\hline & $\operatorname{High}(3.0 \mathrm{kPa})$ & $0.231^{\mathrm{c}}$ & $11.2^{\mathrm{b}}$ & $0.0206^{\mathrm{b}}$ & $0.0283^{\mathrm{b}}$ & $0.727^{\mathrm{b}}$ & $0.293^{\mathrm{b}}$ & $15.2^{\mathrm{a}}$ & $0.0194^{\mathrm{b}}$ & $0.0257^{\mathrm{b}}$ & $0.754^{\mathrm{a}}$ \\
\hline \multirow{3}{*}{$\begin{array}{l}\text { ANOVA } \\
(P \text { value })\end{array}$} & VPD & $<0.001$ & $<0.001$ & 0.091 & 0.548 & 0.002 & 0.003 & 0.706 & 0.003 & 0.002 & 0.224 \\
\hline & Salinity & $<0.001$ & 0.002 & $<0.001$ & $<0.001$ & 0.081 & $<0.001$ & 0.582 & $<0.001$ & $<0.001$ & 0.001 \\
\hline & VPD $\times$ salinity & 0.017 & 0.002 & 0.021 & 0.003 & 0.005 & 0.089 & 0.634 & 0.008 & 0.003 & 0.066 \\
\hline
\end{tabular}




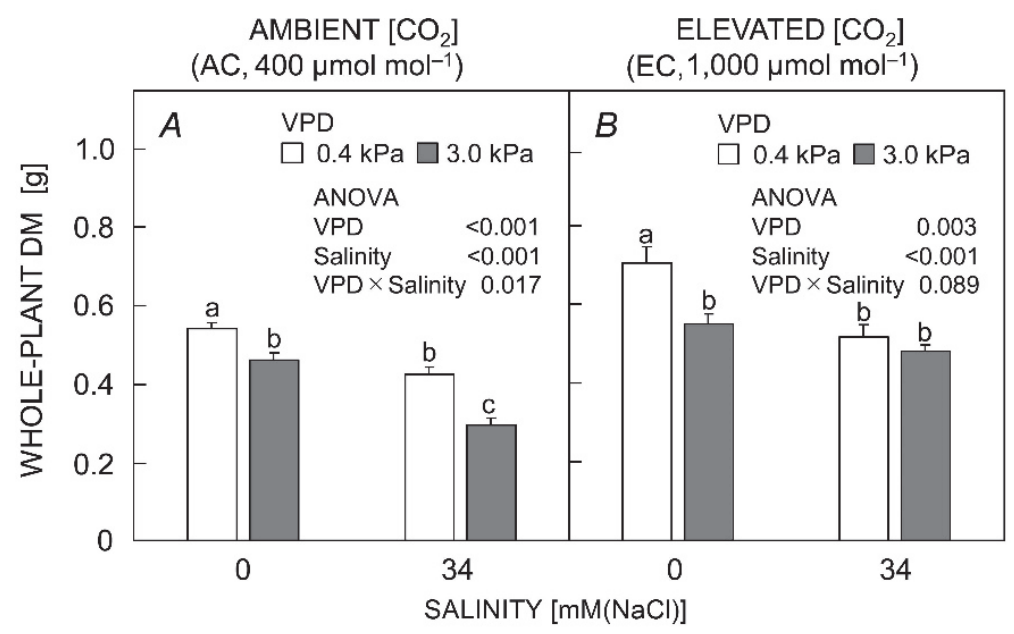

Fig. 1. Whole-plant dry mass (DM) of cucumber (Cucumis sativus) grown under different combinations of vapor-pressure deficit, salinity of the nutrient solution, and atmospheric $\mathrm{CO}_{2}$ concentration $\left(\left[\mathrm{CO}_{2}\right] ;[A]\right.$ ambient $\left[\mathrm{CO}_{2}\right], \mathrm{AC}$, and $[B]$ elevated $\left.\left[\mathrm{CO}_{2}\right], \mathrm{EC}\right)$ for $8 \mathrm{~d}$ after transplantation. Data are average $\pm \mathrm{SE}(n=10)$, except for the combination of low VPD, low salinity, and ambient $\left[\mathrm{CO}_{2}\right]$ $(n=9)$. At a given $\left[\mathrm{CO}_{2}\right]$, mean values labelled with different letters, differed significantly between treatments (Tukey-Kramer test, $P<0.05)$. The statistical analyses were performed after logarithmic transformation of the DM.

Table 2. Net photosynthetic rate $\left(P_{\mathrm{N}}\right)\left[\mu \mathrm{mol}\left(\mathrm{CO}_{2}\right) \mathrm{m}^{-2} \mathrm{~s}^{-1}\right]$, stomatal conductance $\left(g_{\mathrm{s}}\right)\left[\mathrm{mmol}\left(\mathrm{H}_{2} \mathrm{O}\right) \mathrm{m}^{-2} \mathrm{~s}^{-1}\right]$, intercellular $\mathrm{CO}_{2}$ concentration $\left(C_{\mathrm{i}}\right)$ [ $\left.\mu \mathrm{mol} \mathrm{mol}^{-1}\right]$, and leaf water potential $\left(\Psi_{1}\right)$ [MPa] of cucumber (Cucumis sativus) seedlings grown under different combinations of vapor-pressure deficit, salinity of the nutrient solution, and atmospheric $\mathrm{CO}_{2}$ concentration $\left(\left[\mathrm{CO}_{2}\right]\right.$; ambient $\left[\mathrm{CO}_{2}\right]$, $\mathrm{AC}$, and elevated $\left.\left[\mathrm{CO}_{2}\right], \mathrm{EC}\right)$ for $8 \mathrm{~d}$ after transplantation. The $P_{\mathrm{N}}, g_{\mathrm{s}}$, and $C_{\mathrm{i}}$ were measured at a photosynthetic photon flux density of $300 \mu \mathrm{mol} \mathrm{m}^{-2} \mathrm{~s}^{-1}$ and cuvette $\left[\mathrm{CO}_{2}\right]$ of 400 and $1,000 \mu \mathrm{mol} \mathrm{mol}^{-1}$, respectively, for seedlings that were grown under AC and EC. Measurements were conducted at the end of treatment period ( $8 \mathrm{~d}$ after transplantation). Data are the average of five replicate plants $(n=5)$. Mean values of a parameter for a given $\left[\mathrm{CO}_{2}\right]$ that are labelled with different letters, differ significantly (Tukey-Kramer's test, $P<0.05)$.

\begin{tabular}{llllllllll}
\hline Salinity & \multirow{2}{*}{ VPD } & \multicolumn{3}{c}{$\mathrm{AC}\left(400 \mu \mathrm{mol} \mathrm{mol} \mathrm{m}^{-1}\right)$} & \multicolumn{4}{c}{ EC $\left(1,000 \mu \mathrm{mol} \mathrm{mol}^{-1}\right)$} & $\Psi_{1}$ \\
& & $P_{\mathrm{N}}$ & $g_{\mathrm{s}}$ & $C_{\mathrm{i}}$ & $\Psi_{1}$ & $P_{\mathrm{N}}$ & $g_{\mathrm{s}}$ & $C_{\mathrm{i}}$ & $\Psi^{\mathrm{a}}$ \\
\hline Low & Low $(0.4 \mathrm{kPa})$ & $15.1^{\mathrm{a}}$ & $2.05^{\mathrm{a}}$ & $375^{\mathrm{a}}$ & $-0.67^{\mathrm{a}}$ & $17.0^{\mathrm{a}}$ & $1.94^{\mathrm{a}}$ & $968^{\mathrm{a}}$ & $-0.65^{\mathrm{a}}$ \\
$(0 \mathrm{mM} \mathrm{NaCl})$ & High $(3.0 \mathrm{kPa})$ & $14.8^{\mathrm{a}}$ & $0.75^{\mathrm{b}}$ & $348^{\mathrm{b}}$ & $-0.68^{\mathrm{ab}}$ & $16.7^{\mathrm{ab}}$ & $0.64^{\mathrm{c}}$ & $918^{\mathrm{c}}$ & $-0.75^{\mathrm{ab}}$ \\
High & & & & & & & & & \\
$(34 \mathrm{mM} \mathrm{NaCl})$ & High $(3.0 \mathrm{kPa})$ & $14.6^{\mathrm{a}}$ & $1.60^{\mathrm{a}}$ & $372^{\mathrm{a}}$ & $-0.85^{\mathrm{c}}$ & $16.9^{\mathrm{a}}$ & $1.25^{\mathrm{b}}$ & $961^{\mathrm{b}}$ & $-0.83^{\mathrm{b}}$ \\
ANOVA & $12.2^{\mathrm{b}}$ & $0.28^{\mathrm{b}}$ & $308^{\mathrm{c}}$ & $-0.84^{\mathrm{bc}}$ & $16.5^{\mathrm{b}}$ & $0.42^{\mathrm{c}}$ & $891^{\mathrm{c}}$ & $-0.88^{\mathrm{bc}}$ \\
$(P$ value $)$ & VPD & $<0.001$ & $<0.001$ & $<0.001$ & 0.981 & 0.001 & $<0.001$ & $<0.001$ & 0.020 \\
& Salinity & $<0.001$ & 0.004 & $<0.001$ & 0.001 & 0.144 & 0.004 & 0.007 & $<0.001$ \\
& VPD $\times$ salinity & $<0.001$ & 0.938 & $<0.001$ & 0.833 & 0.666 & 0.099 & 0.070 & 0.322 \\
\hline
\end{tabular}

Photosynthetic properties and water status: There was a significant VPD $\times$ salinity interaction for $P_{\mathrm{N}}$ under $\mathrm{AC}$; high VPD did not affect $P_{\mathrm{N}}$ at low salinity, but significantly decreased $P_{\mathrm{N}}$ at high salinity, to $84 \%$ of the value at low VPD (Table 2). No significant interaction was observed under EC; VPD and salinity had little influence on $P_{\mathrm{N}}$, although high VPD slightly decreased $P_{\mathrm{N}}$ (by about $2 \%$ ). These results were similar to the results for NAR (Table 1). There was no significant VPD $\times$ salinity interaction for $g_{\mathrm{s}}$ at either $\left[\mathrm{CO}_{2}\right] ; g_{\mathrm{s}}$ decreased greatly and significantly at high VPD and high salinity under both $\left[\mathrm{CO}_{2}\right] . C_{\mathrm{i}}$ decreased significantly both at high VPD and at high salinity under both $\left[\mathrm{CO}_{2}\right]$. The order of $C_{\mathrm{i}}$ values among the treatments was the same as the order of $g_{\mathrm{s}}$ at both $\left[\mathrm{CO}_{2}\right]$, though the proportional decrease was smaller for $C_{\mathrm{i}}$.
$\Psi_{1}$ was lower (more negative) at high salinity under both $\left[\mathrm{CO}_{2}\right]$, but was not significantly affected by VPD at either salinity level (Table 2).

The $P_{\mathrm{N}}-C_{\mathrm{i}}$ curve measured at a PPFD of $300 \mu \mathrm{mol}$ $\mathrm{m}^{-2} \mathrm{~s}^{-1}$ (the same as the growth conditions) was similar at both $\left[\mathrm{CO}_{2}\right]$ conditions and did not much differ between the treatment groups (Fig. $2 A, B$ ). Table 3 summarizes the electron transport and carboxylation values. The $J_{300}$ value, which was estimated from these curves, was not significantly affected by VPD and salinity under both $\left[\mathrm{CO}_{2}\right]$. In addition, the $V_{\text {cmax }}$ and $J_{1500}$ values, which were estimated from the $P_{\mathrm{N}}-C_{\mathrm{i}}$ curves at saturating light intensity (Fig. $2 C, D)$, were also not significantly affected by VPD and salinity, although $V_{\text {cmax }}$ tended to be lower at high salinity. These results indicate that the mesophyll photosynthetic capacity did not much differ between the treatment groups. 


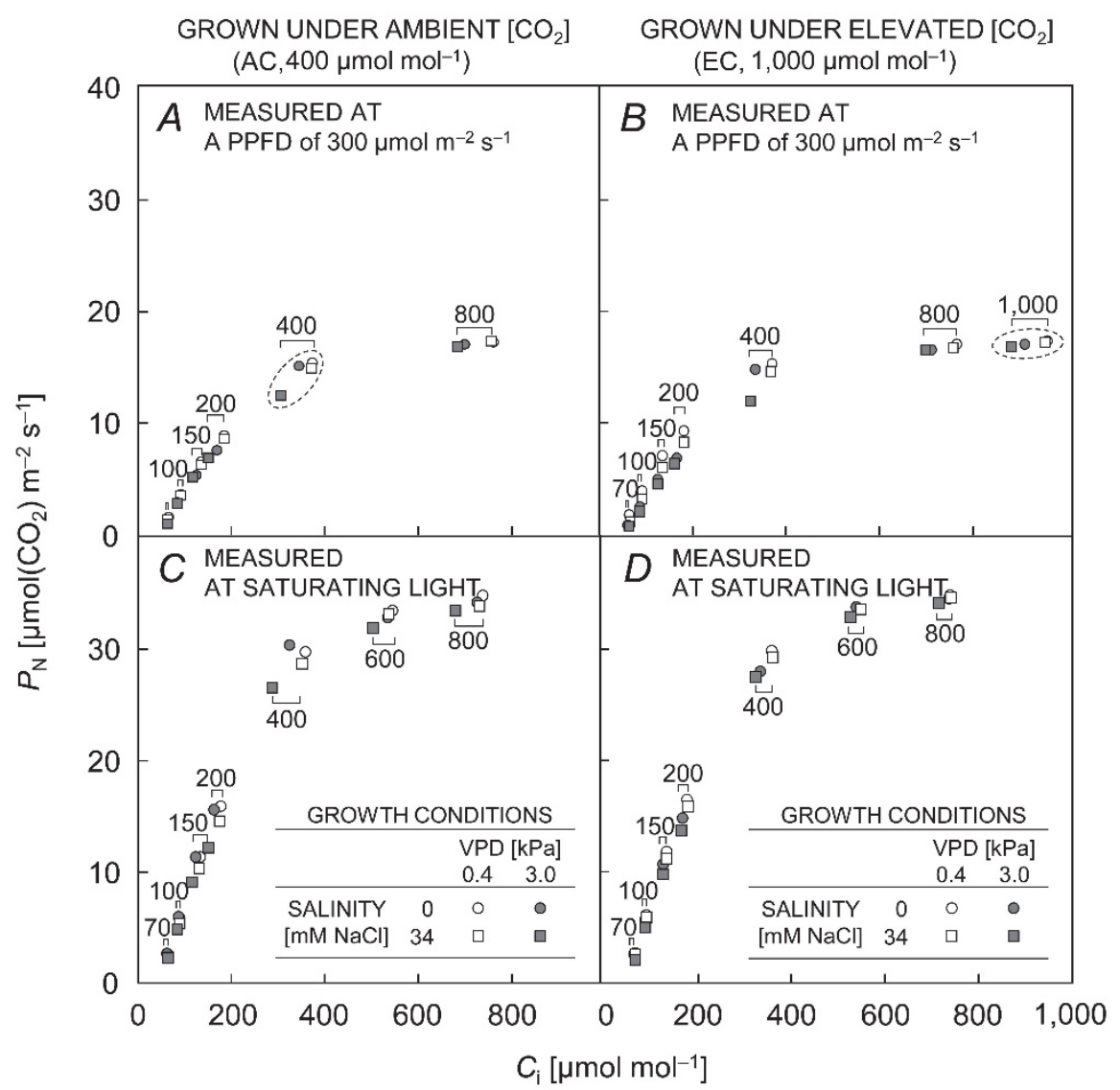

Fig. 2. Relationships between the intercellular $\mathrm{CO}_{2}$ concentration $\left(C_{\mathrm{i}}\right)$ and the net photosynthetic rate $\left(P_{\mathrm{N}}\right)$ for cucumber $(C u c u m i s$ sativus) seedlings grown under different combinations of vapor-pressure deficit, salinity of the nutrient solution, and atmospheric $\mathrm{CO}_{2}$ concentration $\left(\left[\mathrm{CO}_{2}\right] ;[A, C]\right.$ ambient $\left[\mathrm{CO}_{2}\right], \mathrm{AC}$, and $[B, D]$ elevated $\left.\left[\mathrm{CO}_{2}\right], \mathrm{EC}\right)$ for $8 \mathrm{~d}$ after transplantation. Photosynthesis was measured at a PPFD of $(A, B) 300$ and $(C, D) 1,500$ (saturating light) $\mu \mathrm{mol}$ (photon) $\mathrm{m}^{-2} \mathrm{~s}^{-1}$. The values above the symbols are the $\left[\mathrm{CO}_{2}\right]$ value for each measurement. The symbols enclosed by dashed lines indicate values measured at the same PPFD and $\left[\mathrm{CO}_{2}\right]$ as the growth conditions (the $P_{\mathrm{N}}$ and $C_{\mathrm{i}}$ values of these symbols are shown in Table 2). Measurements were conducted at the end of treatment period ( $8 \mathrm{~d}$ after transplantation). Data are the average of five replicate plants $(n=5)$.

Table 3. Electron transport rates at a PPFD of $300 \mu \mathrm{mol} \mathrm{m}{ }^{-2} \mathrm{~s}^{-1}\left(J_{300}\right)\left[\mu \mathrm{mol}\left(\mathrm{e}^{-}\right) \mathrm{m}^{-2} \mathrm{~s}^{-1}\right]$ and $1,500 \mu \mathrm{mol} \mathrm{m}^{-2} \mathrm{~s}^{-1}\left(J_{1500}\right)\left[\mu \mathrm{mol}\left(\mathrm{e}^{-}\right) \mathrm{m}^{-2} \mathrm{~s}^{-1}\right]$, and the maximum rate of Rubisco carboxylase activity $\left(V_{\mathrm{cmax}}\right)\left[\mu \mathrm{mol}\left(\mathrm{CO}_{2}\right) \mathrm{m}^{-2} \mathrm{~s}^{-1}\right]$ of cucumber $($ Cucumis sativus) seedlings grown

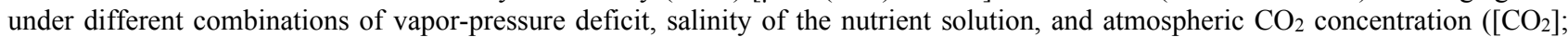
ambient $\left[\mathrm{CO}_{2}\right], \mathrm{AC}$, and elevated $\left.\left[\mathrm{CO}_{2}\right], \mathrm{EC}\right)$ for $8 \mathrm{~d}$ after transplantation. Values of $J_{300}$ were estimated from the relationships between net photosynthetic rate $\left(P_{\mathrm{N}}\right)$ and the intercellular $\mathrm{CO}_{2}$ concentration $\left(C_{\mathrm{i}}\right)$ measured at a PPFD of $300 \mu \mathrm{mol} \mathrm{m}^{-2} \mathrm{~s}^{-1}$ (Fig. 2A,B). Values of $J_{1500}$ and $V_{\text {cmax }}$ were estimated from the relationships between $P_{\mathrm{N}}$ and $C_{\mathrm{i}}$ measured at a PPFD of 1,500 $\mu \mathrm{mol} \mathrm{m}^{-2} \mathrm{~s}^{-1}(\mathrm{Fig} .2 C, D)$. Measurements were conducted at the end of treatment period ( $8 \mathrm{~d}$ after transplantation). Data are the average of five replicate plants $(n=5)$. Mean values of a parameter for a given $\left[\mathrm{CO}_{2}\right]$ that are labelled with different letters, differ significantly (Tukey-Kramer's test, $P<0.05)$

\begin{tabular}{llllllll}
\hline Salinity & \multirow{2}{*}{ VPD } & \multicolumn{2}{c}{$\mathrm{AC}\left(400 \mu \mathrm{mol} \mathrm{mol}{ }^{-1}\right)$} & \multicolumn{3}{c}{ EC $\left(1,000 \mu \mathrm{mol} \mathrm{mol}^{-1}\right)$} \\
& & $J_{300}$ & $J_{1500}$ & $V_{\text {cmax }}$ & $J_{300}$ & $J_{1500}$ & $V_{\text {cmax }}$ \\
\hline Low & Low $(0.4 \mathrm{kPa})$ & $96^{\mathrm{a}}$ & $170^{\mathrm{a}}$ & $129^{\mathrm{a}}$ & $90^{\mathrm{a}}$ & $169^{\mathrm{a}}$ & $128^{\mathrm{a}}$ \\
$(0 \mathrm{mM} \mathrm{NaCl})$ & High $(3.0 \mathrm{kPa})$ & $97^{\mathrm{a}}$ & $168^{\mathrm{a}}$ & $132^{\mathrm{a}}$ & $96^{\mathrm{a}}$ & $168^{\mathrm{a}}$ & $131^{\mathrm{a}}$ \\
High & Low $(0.4 \mathrm{kPa})$ & $94^{\mathrm{a}}$ & $168^{\mathrm{a}}$ & $121^{\mathrm{a}}$ & $93^{\mathrm{a}}$ & $168^{\mathrm{a}}$ & $124^{\mathrm{a}}$ \\
$(34 \mathrm{mM} \mathrm{NaCl})$ & High $(3.0 \mathrm{kPa})$ & $94^{\mathrm{a}}$ & $165^{\mathrm{a}}$ & $119^{\mathrm{a}}$ & $93^{\mathrm{a}}$ & $169^{\mathrm{a}}$ & $127^{\mathrm{a}}$ \\
ANOVA & VPD & 0.516 & 0.306 & 0.869 & 0.124 & 0.858 & 0.323 \\
& Salinity & 0.262 & 0.207 & 0.077 & 0.794 & 0.706 & 0.207 \\
& VPD $\times$ salinity & 0.311 & 0.964 & 0.676 & 0.167 & 0.362 & 0.935 \\
\hline
\end{tabular}


Interaction between VPD and $\left[\mathrm{CO}_{2}\right]$ : There were significant VPD $\times\left[\mathrm{CO}_{2}\right]$ interactions for $\mathrm{RGR}(P=0.024)$, NAR $(P=0.023), P_{\mathrm{N}}(P<0.001)$, and $g_{\mathrm{s}}(P<0.001)$ at high salinity, with a stronger VPD effect at AC, but insignificant interactions were observed at low salinity (RGR,

\section{Discussion}

Effect of salinity: In general, salinity reduces the plant growth and photosynthesis due to two phases: osmotic and ionic (Munns and Tester 2008). Chen et al. (2015) indicates that osmotic stress strongly affects $g_{\mathrm{s}}$, but has no influence on photosynthetic capacity whereas ionic stress affects both. The high salinity treatment $(34 \mathrm{mM} \mathrm{NaCl})$ possibly reduces the photosynthetic capacity of cucumber through ionic effect (Drew et al. 1990, Chen et al. 2015), but did not appear to affect significantly this capacity in the present study. Thus, we consider that the salinity effects, which were observed in the present study, were mainly due to osmotic stress, although the effects of two phases could not be fully separated.

Growth analysis: The RGR is the product of NAR, which is largely the net result of carbon gain and carbon losses expressed per unit of leaf area, and LAR, which is the ratio of leaf area to whole-plant mass (i.e., $\mathrm{RGR}=\mathrm{NAR} \times \mathrm{LAR}$ ) (Poorter and Remkes 1990). The results for these parameters explain why the growth inhibition, which occurs with increasing VPD, differed between salinity and $\mathrm{CO}_{2}$ concentrations. Under AC, high VPD significantly inhibited growth under both high and low salinity, but the underlying causal factors differed. At low salinity, the decrease in RGR with increasing VPD resulted from significantly decreased LAR, whereas the decrease in RGR at high salinity was due to significantly decreased NAR. The decrease in LAR at low salinity was mainly due to significantly reduced SLA. These results suggest that the growth inhibition caused by high evaporative demand resulted mainly from a reduction of leaf enlargement per unit of leaf DM under well-watered conditions, but resulted mainly from a reduction of net photosynthesis per unit of leaf area under water deficit conditions. This is of interest for greenhouse growers that aim to optimize environmental conditions, because, for example, $\mathrm{CO}_{2}$ fertilization could mitigate growth inhibition caused by high VPD for situations in which such inhibition is mainly a result of a low NAR.

VPD $\times$ salinity interaction for photosynthesis: The significant VPD $\times$ salinity interaction for NAR under AC, which we observed in the present study, is similar to a previous report, in which the photosynthesis of fieldgrown winter wheat decreased with increased VPD at a low soil water potential but did not respond to increased VPD at a high soil water potential (Xue et al. 2004). This phenomenon can be explained based on the relationships between $P_{\mathrm{N}}$ and $C_{\mathrm{i}}$ obtained in the present study.
$P=0.421 ;$ NAR, $\left.P=0.732, P_{\mathrm{N}}, P=0.945 ; g_{\mathrm{s}}, P=0.993\right)$. In addition, insignificant VPD $\times\left[\mathrm{CO}_{2}\right]$ interaction was observed for LAR at high and low salinity $(P=0.610$ and $P=0.302$, respectively).

At low salinity, $P_{\mathrm{N}}$ was not reduced by the high VPD, whereas $g_{\mathrm{s}}$ decreased greatly and significantly in the same way described in our previous report (Shibuya et al. $2016 \mathrm{~b})$. In general, $P_{\mathrm{N}}$ is limited by both stomatal and nonstomatal (mesophyll) factors. The lack of significant differences in the values of $J_{300}, J_{1500}$, and $V_{\text {cmax }}$ between the high and low VPD levels indicates that the mesophyll photosynthetic capacity (a nonstomatal factor) was not much altered by VPD in the present study. The $P_{\mathrm{N}}-C_{\mathrm{i}}$ curve indicates that, at low salinity, the observed decrease in $g_{\mathrm{s}}$ would decrease $C_{\mathrm{i}}$ in a range where this would have only a small effect on $P_{\mathrm{N}}$ under AC (Fig. $2 A$ ). Therefore, the decreased $g_{\mathrm{s}}$ caused by higher VPD did not significantly reduce $P_{\mathrm{N}}$ by reducing $C_{\mathrm{i}}$ at low salinity. At high salinity, the observed decrease in $g_{\mathrm{s}}$ would decrease $C_{\mathrm{i}}$ in a range where this would have a considerable effect on $P_{\mathrm{N}}$ (i.e., the part of the curve $P_{\mathrm{N}}-C_{\mathrm{i}}$ with the steeper slopes (Fig. 2A). This difference in responses between high and low salinity may be responsible for the significant VPD $\times$ salinity interaction observed for $P_{\mathrm{N}}$ at $\mathrm{AC}$ and, consequently, for the significant decrease in NAR at high salinity.

The insignificant reduction of photosynthetic capacity caused by increasing VPD probably resulted from the fact that the high VPD did not decrease $\Psi_{1}$ sufficiently to affect photosynthesis although a reduction of $\Psi_{1}$ can inhibit photosynthetic capacity (Keck and Boyer 1974, Flexas and Medrano 2002, Lawlor 2002). In addition, the higher VPD greatly reduced $g_{\mathrm{s}}$ in all treatments, and this decrease would potentially maintain $\Psi_{1}$ at non-damaging levels by decreasing water loss. This probably resulted from feedforward responses of the stomata to atmospheric moisture contents (Lange et al. 1971, Farquhar 1978, Grantz 1990, Saliendra et al. 1995, Bunce 1997, Buckley 2005, Peak and Mott 2011).

Effect of EC on photosynthesis: Under EC, there was little effect of VPD on $P_{\mathrm{N}}$. This is due to the fact that the decrease in $C_{\mathrm{i}}$ with decreasing $g_{\mathrm{s}}$ occurred within the range of the $P_{\mathrm{N}}-C_{\mathrm{i}}$ curve where the slopes were almost flat because of the higher $\left[\mathrm{CO}_{2}\right]$ (the symbols enclosed by dashed line in Fig. 2B), as reported by Wong (1993). On the other hand, at AC, higher VPD significantly decreased $P_{\mathrm{N}}$ at high salinity. This difference resulted in a significant VPD $\times\left[\mathrm{CO}_{2}\right]$ interaction for $P_{\mathrm{N}}$ only at high salinity; the $\left[\mathrm{CO}_{2}\right]$ effect on $P_{\mathrm{N}}$ was greater at high VPD. This agrees with previous reports that the effect of EC on photosynthesis is greater under conditions with greater water stress (Wong 1993, Newton et al. 1996, Mishra et al. 1999, 
Poorter and Pérez-Soba 2001, Pérez-López et al. 2013), although a contradictory result, in which EC did not reduce the sensitivity of $P_{\mathrm{N}}$ to VPD, has also been reported (Bunce 2003).

Our results seem conflict with a previous report that $\mathrm{CO}_{2}$ fertilization had a greater effect on greenhouse-grown plants at lower VPD (Gislerød and Nelson 1989). This contradiction may be explained by the response of leaf expansion to evaporative demand. In the present study, the greatest seedling growth (RGR and DM) under EC was observed at low VPD, and this was caused by increased leaf expansion (LAR) but not by increased photosynthesis (NAR). Our results indicate that the VPD $\times$ salinity (probably osmotic potential) interaction for LAR should be considered when investigating the simultaneous effects of $\left[\mathrm{CO}_{2}\right]$ and VPD on plant growth.

VPD $\times$ salinity interaction for LAR: The reduction of SLA, which seems to be the main factor responsible for the smaller LAR, at high VPD and high salinity may be partly due to a decrease in water availability to support cell expansion (Poorter et al. 2009), a process that competes with transpiration (McIntyre and Boyer 1984, Westgate and Boyer 1984, Waldron and Terry 1987, Pantin et al. 2012). However, the reduction at high VPD cannot be fully explained by changes in the water balance, because the change in LAR was not clearly related to the change in $\Psi_{1}$. This is probably because evaporative demand potentially controls leaf expansion without changing $\Psi_{1}$ (Salah and Tardieu 1997, Munns et al. 2000, Tardieu et al. 2000, 2010). In addition, a water deficit in the rhizosphere can directly control leaf expansion through signal transduction

\section{References}

Ben-Asher J., Garcia A.G., Flitcroft I., Hoogenboom G.: Effect of atmospheric water vapor on photosynthesis, transpiration and canopy conductance: A case study in corn. - Plant Soil Environ. 59: 549-555, 2013.

Buckley T.N.: The control of stomata by water balance. - New Phytol. 168: 275-292, 2005.

Bunce J.A.: Does transpiration control stomatal responses to water vapour pressure deficit? - Plant Cell Environ. 20: 131135, 1997.

Bunce J.A.: Effects of water vapor pressure difference on leaf gas exchange in potato and sorghum at ambient and elevated carbon dioxide under field conditions. - Field Crop. Res. 82: 37-47, 2003.

Carins-Murphy M.R., Jordan G.J., Brodribb T.J.: Acclimation to humidity modifies the link between leaf size and the density of veins and stomata. - Plant Cell Environ. 37: 124-131, 2014

Chen T.W., Kahlen K., Stützel H.: Disentangling the contributions of osmotic and ionic effects of salinity on stomatal, mesophyll, biochemical and light limitations to photosynthesis. - Plant Cell Environ. 38: 1528-1542, 2015.

Dai Z., Edwards G.E., Ku M.S. Control of photosynthesis and stomatal conductance in Ricinus communis L. (castor bean) by leaf to air vapor pressure deficit. - Plant Physiol. 99: 14261434, 1992. pathways mediated by abscisic acid (Passioura 1988, Davies and Zhang 1991, Fricke et al. 2004, Liu et al. 2006, Zhang et al. 2006). The ionic stress also can induce the increase in leaf mass per area (the inverse of SLA) (Poorter et al. 2009). These responses are possible reasons for the reduction of LAR in response to high VPD and high salinity.

Tardieu et al. (2000) reported that evaporative demand and rhizosphere water potential independently affected leaf expansion, with near-additive effects. This does not agree with our results, in which the interaction between VPD and salinity (probably osmotic stress) significantly affected LAR at both $\left[\mathrm{CO}_{2}\right]$. The significant VPD $\times$ salinity interaction for LAR, which we observed, suggests that a common underlying mechanism mediated the decreased leaf expansion caused by increasing evaporative demand and increasing salinity stress.

Conclusions: The evaporative demand and salinity interactively affected the growth and photosynthetic properties of cucumber seedlings, and these interactions differed between ambient and elevated atmospheric $\mathrm{CO}_{2}$ concentrations. The increase in VPD reduced the seedlings' growth mainly by reducing LAR at low salinity, but by decreasing NAR at high salinity. In addition, under elevated $\mathrm{CO}_{2}$, VPD also affected LAR, but not NAR. Such complex interactions resulted from the interactions among and individual effects of these environmental factors on photosynthesis and expansion growth in complicated ways. The underlying factors responsible for these interactions will provide important clues about the complexity of plant growth under fluctuating environments.

Davies W.J., Zhang J.: Root signals and the regulation of growth and development of plants in drying soil. - Annu. Rev. Plant Biol. 42: 55-76, 1991.

Drew M.C., Hold P.S., Picchioni G.A.: Inhibition by $\mathrm{NaCl}$ of net $\mathrm{CO}_{2}$ fixation and yield of cucumber. - J. Am. Soc. Hortic. Sci. 115: 472-477, 1990.

El-Sharkawy M.A.: Overview: Early history of crop growth and photosynthesis modeling. - BioSystems 103: 205-211, 2011.

Flexas J., Medrano H.: Drought - inhibition of photosynthesis in C3 plants: stomatal and non-stomatal limitations revisited. Ann. Bot.-London 89: 183-189, 2002.

Fricke W., Akhiyarova G., Veselov D., Kudoyarova G.: Rapid and tissue - specific changes in ABA and in growth rate in response to salinity in barley leaves. - J. Exp. Bot. 55: 11151123,2004

Farquhar G.D.: Feedforward responses of stomata to humidity. Funct. Plant Biol. 5: 787-800, 1978.

Gislerød H.R., Nelson P.V.: The interaction of relative air humidity and carbon dioxide enrichment in the growth of Chrysanthemum $\times$ morifolium Ramat. - Sci. Hortic.-Amsterdam 38: 305-313, 1989.

Grantz D.A.: Plant response to atmospheric humidity. - Plant Cell Environ. 13: 667-679, 1990.

Hunt R., Causton D.R., Shipley B., Askew A.P.: A modern tool for 
classical plant growth analysis. - Ann. Bot. 90: 485-488, 2002.

Keck R.W., Boyer J.S.: Chloroplast response to low leaf water potentials III. Differing inhibition of electron transport and photophosphorylation. - Plant Physiol. 53: 474-479, 1974.

Körner O., Challa H.: Process-based humidity control regime for greenhouse crops. - Comput. Electron. Agr. 39: 173-192, 2003.

Lange O.L., Lösch R., Schulze E.D., Kappen L.: Responses of stomata to changes in humidity. - Planta 100: 76-86, 1971.

Lawlor D.W.: Limitation to photosynthesis in water-stressed leaves: stomata vs. metabolism and the role of ATP. - Ann. Bot.-London 89: 871-885, 2002.

Liu F., Shahnazari A., Andersen M.N. et al.: Physiological responses of potato (Solanum tuberosum L.) to partial rootzone drying: ABA signalling, leaf gas exchange, and water use efficiency. - J. Exp. Bot. 57: 3727-3735, 2006.

Lu N., Nukaya T., Kamimura T. et al.: Control of vapor pressure deficit (VPD) in greenhouse enhanced tomato growth and productivity during the winter season. - Sci. Hortic.Amsterdam 197: 17-23, 2015.

McIntyre G.I., Boyer J.S.: The effect of humidity, root excision, and potassium supply on hypocotyl elongation in dark-grown seedlings of Helianthus annuus. - Can. J. Bot. 62: 420-428, 1984.

Mishra R.S., Abdin M.Z., Uprety D.C.: Interactive effects of elevated $\mathrm{CO}_{2}$ and moisture stress on the photosynthesis, water relation and growth of Brassica species. - J. Agron. Crop. Sci. 182: 223-230, 1999.

Munns R., Passioura J.B., Guo J. et al.: Water relations and leaf expansion: importance of time scale. - J. Exp. Bot. 51: 14951504,2000

Munns R., Tester M.: Mechanisms of salinity tolerance. - Annu. Rev. Plant Biol. 59: 651-681, 2008.

Newton P.C.D., Clark H., Bell C.C., Glasgow E.M.: Interaction of soil moisture and elevated $\mathrm{CO}_{2}$ on the above-ground growth rate, root length density and gas exchange of turves from temperate pasture. - J. Exp. Bot. 47: 771-779, 1996.

Ottosen C.O., Mortensen L.M., Gislerød H.R.: Effect of relative air humidity on gas exchange, stomatal conductance and nutrient uptake in miniature potted roses. - Gartenbauwissenschaft 67: 143-147, 2002.

Pantin F., Simonneau T., Muller B.: Coming of leaf age: control of growth by hydraulics and metabolics during leaf ontogeny. - New Phytol. 196: 349-366, 2012.

Passioura J.B.: Root signals control leaf expansion in wheat seedlings growing in drying soil. - Funct. Plant Biol. 15: 687693, 1988

Peak D., Mott K.A.: A new, vapour-phase mechanism for stomatal responses to humidity and temperature. - Plant Cell Environ. 34: 162-178, 2011.

Pérez-López U., Miranda-Apodaca J., Mena-Petite A., MuñozRueda A.: Barley growth and its underlying components are affected by elevated $\mathrm{CO}_{2}$ and salt concentration. - J. Plant Growth Regul. 32: 732-744, 2013.

Poorter H., Niinemets U., Poorter L. et al.: Causes and consequences of variation in leaf mass per area (LMA): a metaanalysis. - New Phytol. 182: 565-588, 2009.

Poorter H., Pérez-Soba M.: The growth response of plants to elevated $\mathrm{CO}_{2}$ under non-optimal environmental conditions. Oecologia 129: 1-20, 2001.

Poorter H., Remkes C.: Leaf area ratio and net assimilation rate of 24 wild species differing in relative growth rate. - Oecologia
83: 553-559, 1990.

Radford P.J.: Growth analysis formulae - their use and abuse. Crop Sci. 7: 171-175, 1967.

Raschke K., Resemann A.: The midday depression of $\mathrm{CO}_{2}$ assimilation in leaves of Arbutus unedo L.: diurnal changes in photosynthetic capacity related to changes in temperature and humidity. - Planta 168: 546-558, 1986.

Richards L.A.: Diagnosis and improvement of saline and alkali soils. - Soil Sci. 120: 800-826, 1954

Salah H.B.H., Tardieu F.: Control of leaf expansion rate of droughted maize plants under fluctuating evaporative demand. A superposition of hydraulic and chemical messages? - Plant Physiol. 114: 893-900, 1997.

Saliendra, N.Z., Sperry, J.S., Comstock, J.P.: Influence of leaf water status on stomatal response to humidity, hydraulic conductance, and soil drought in Betula occidentalis. - Planta 196: $357-366,1995$

Sharkey T.D., Bernacchi C.J., Farquhar G.D., Singsaas E.L.: Fitting photosynthetic carbon dioxide response curves for $\mathrm{C} 3$ leaves. - Plant Cell Environ. 30: 1035-1040, 2007.

Shibuya T., Hayashi S., Endo R., Kitaya Y.: Growth analysis and photosynthesis measurements of cucumber seedlings grown under light with different red to far-red ratios. - HortScience 51: 843-846, 2016a.

Shibuya T., Kano K., Endo R., Kitaya Y.: Photosynthetic properties and response to drought in cucumber seedlings acclimatized to different vapor-pressure-deficit levels. - Hortic J.: doi: 10.2503/hortj.MI-154, 2016b.

Tardieu F., Parent B., Simonneau T.: Control of leaf growth by abscisic acid: hydraulic or non-hydraulic processes? - Plant Cell Environ. 33: 636-647, 2010.

Tardieu F., Reymond M., Hamard P. et al.: Spatial distributions of expansion rate, cell division rate and cell size in maize leaves: a synthesis of the effects of soil water status, evaporative demand and temperature. - J. Exp. Bot. 51: 1505-1514, 2000.

van de Sanden P.A., Veen B.W.: Effects of air humidity and nutrient solution concentration on growth, water potential and stomatal conductance of cucumber seedlings. - Sci. Hortic.Amsterdam 50: 173-186, 1992.

von Caemmerer S., Farquhar G.D.: Some relationships between the biochemistry of photosynthesis and the gas exchange of leaves. - Planta 153: 376-387, 1981.

Waldron L.J., Terry N.: The influence of atmospheric humidity on leaf expansion in Beta vulgaris L. - Planta 170: 336-342, 1987.

Westgate M.E., Boyer J.S.: Transpiration-and growth-induced water potentials in maize. - Plant Physiol. 74: 882-889, 1984.

Wong S.C.: Interaction between elevated atmospheric concentration of $\mathrm{CO}_{2}$ and humidity on plant growth: comparison between cotton and radish. - Vegetatio 104: 211-221, 1993.

Xue Q., Weiss A., Arkebauer T.J., Baenziger P.S.: Influence of soil water status and atmospheric vapor pressure deficit on leaf gas exchange in field-grown winter wheat. - Environ. Exp. Bot. 51: 167-179, 2004.

Zhang D., Zhang Z., Li J. et al.: Regulation of vapor pressure deficit by greenhouse micro-fog systems improved growth and productivity of tomato via enhancing photosynthesis during summer season. - PLoS ONE 10: e 0133919, 2015.

Zhang J., Jia W., Yang J., Ismail A.M.: Role of ABA in integrating plant responses to drought and salt stresses. - Field Crop. Res. 97: 111-119, 2006. 